\title{
Ileocecal Valve Lipomatosis: Evaluation by Computed Tomography
}

\section{Manisha Narayanbhai Solanki ${ }^{1}$, Vasant Kumar Jethabhai Rathod ${ }^{2}$, Ashish Aravind $^{3}$, Harshil K Aghera ${ }^{3}$}

Sci. Journal Impact

Factor: $6.1(2018)$

ICV: 90.90 (2018)

(c) (i) (3)

Copyright@IJCRR

\begin{abstract}
'Assistant Professor, Department of Radiology, GMERS Medical College \& Hospital, Sola, Ahmedabad, Gujarat, India; 'Assistant Professor, Department of Radiology, B.j. Medical College \& Civil Hospital, Ahmedabad, Gujarat, India; ${ }^{3 R e s i d e n t ~ D o c t o r, ~ D e p a r t m e n t ~ o f ~ R a d i o l o g y, ~ B . j . ~}$

Medical College \& Civil Hospital, Ahmedabad, Gujarat, India.
\end{abstract}

\section{ABSTRACT}

Introduction: IC (ileocecal) valve lipomatosis is characterized by the deposition of fat in the submucosal layer of the IC valve. CT (computed tomography) scan is highly sensitive \& specific for it.

Objectives: (1) To know how common/uncommon it is to encounter IC valve lipomatosis in day-to-day routine radiology practice (2) To know is there any age or gender predisposition for the development of IC valve lipomatosis (3) To know is there any association of obesity or idiopathic inflammatory bowel disease with IC valve lipomatosis.

Methods: This prospective study included all cases of CT abdomen (plain as well as contrast-enhanced ) performed for any indication from 1st November 2019 to 15th July 2020. Repeat/follow up cases were excluded from our study. Total of 800 cases was evaluated to see the presence/absence of IC valve lipomatosis. Cases of IC valve lipomatosis were evaluated in detail for age, gender, obesity \& other bowel abnormalities.

Results: Out of 800 cases of CT abdomen, 78 cases showed the presence of IC valve lipomatosis. Out of 78 cases of IC valve lipomatosis, 41 were male \& 37 were female. The mean age for the IC valve lipomatosis in our study was 46.7 years. All cases of IC valve lipomatosis showed no evidence of idiopathic inflammatory bowel disease on CT scan.

Conclusion: It is not uncommon to encounter IC valve lipomatosis in day-to-day routine radiology practice even in patients below 40 years of age. We haven't found female predominance or association of idiopathic inflammatory bowel disease with IC valve lipomatosis in our study. Results of our study support the association of obesity with IC valve lipomatosis.

Key Words: IC valve, Lipomatosis, CT scan, Intestine, Bowel, Crohn's disease

\section{INTRODUCTION}

Lipomatosis means a proliferation of normal fat in the soft tissue including the mediastinum, kidneys ( renal sinus), pelvis or the intestine. ${ }^{1}$ IC ( ileocecal ) valve lipomatosis is characterized by deposition of fat in the submucosal layer of lips of the IC valve. Several synonyms have been applied for the IC valve lipomatosis including hypertrophy of the IC valve, lipohyperplasia of IC valve, fatty degeneration of the IC valve and the ileocecal valve syndrome. ${ }^{2}$ As opposed to lipoma, lipomatosis does not have a distinct capsule. CT ( computed tomography ) scan is highly sensitive as well as specific for intestinal lipomatosis including IC valve lipomatosis. Objectives of this study were: (1) To know how common/uncommon it is to encounter IC valve lipomatosis in day-to-day routine radiology practice (2) To know is there any age or gender predisposition for the development of IC valve lipomatosis (3) To know is there any association of obesity or idiopathic inflammatory bowel disease with IC valve lipomatosis.

\section{MATERIALS \& METHODS}

Study type: Prospective study

Study period: $1^{\text {st }}$ November 2019 to $15^{\text {th }}$ July 2020

Study setting: Department of Radiology, B.J. Medical College \& Civil Hospital, Ahmedabad, Gujarat, India.

Sample size: 800 patients

\section{Study procedure}

Study included all cases of CT abdomen (plain as well as contrast-enhanced ) performed for any indication during 8.5

\section{Corresponding Author:}

Dr. Vasantkumar Jethabhai Rathod, Assistant Professor, Department of Radiology, B.J. Medical College \& Civil Hospital, Asarwa, Ahmedabad - 380016, Gujarat, India; Email: rathod.vasant9@gmail.com

ISSN: 2231-2196 (Print)

Received: 20.07 .2020
ISSN: 0975-5241 (Online)

Revised: 01.10 .2020
Accepted: 12.10 .2020

Published: 14.12 .2020 
months from $1^{\text {st }}$ November 2019 to $15^{\text {th }}$ July 2020. Repeat/ follow up cases were excluded from our study. CT scans were performed using SIEMENS SOMATOM Definition AS 128 slice CT scanner. Axial scan of the abdomen was performed in all patients. Total of 800 cases of CT abdomen was evaluated to see the presence/absence of IC valve lipomatosis. Age, gender \& BMI (body mass index) of all patients showing the presence of IC valve lipomatosis on CT scan were recorded. Cases showing the presence of IC valve lipomatosis were evaluated in detail to look for CT findings of other bowel pathologies especially Crohn's disease \& ulcerative colitis.

\section{RESULTS}

\section{Demographic characteristics}

Out of 800 cases, 78 cases $(9.75 \%)$ showed the presence of IC valve lipomatosis. Out of 78 cases, 41 cases (53\%) were male \& 37 cases $(47 \%)$ were female as shown in Table 1. From 78 cases of IC valve lipomatosis, the youngest patient was 18 years old whereas the oldest patient was 73 years old.

\section{Table 1: Age \& Gender Wise Distribution}

\begin{tabular}{lccc} 
Age group & $\begin{array}{c}\text { No. of Male } \\
\text { patients }\end{array}$ & $\begin{array}{c}\text { No. of Female } \\
\text { patients }\end{array}$ & $\begin{array}{c}\text { Total No. of } \\
\text { patients }\end{array}$ \\
\hline 0-20 & 1 & 3 & 4 \\
$21-40$ & 13 & 9 & 22 \\
$41-60$ & 11 & 16 & 27 \\
$61-80$ & 16 & 9 & 25 \\
Total & 41 & 37 & 78 \\
\hline
\end{tabular}

According to BMI ( Body mass index ) out of 78 cases of IC valve lipomatosis, 36 cases ( 20 male \& 16 female ) were either normal or underweight whereas 42 cases ( 21 male \& 21 female ) were either overweight or obese as shown in Table 2 .

Table 2: BMI \& Gender Wise Distribution

\begin{tabular}{|c|c|c|c|}
\hline $\begin{array}{l}\text { Categories according } \\
\text { to BMI }\end{array}$ & $\begin{array}{l}\text { No. of Male } \\
\text { patients }\end{array}$ & $\begin{array}{l}\text { No. of } \\
\text { Female } \\
\text { patients }\end{array}$ & $\begin{array}{c}\text { Total } \\
\text { No. of } \\
\text { patients }\end{array}$ \\
\hline $\begin{array}{l}\text { Underweight } \\
(\mathrm{BMI}<18.5)\end{array}$ & 2 & 7 & 9 \\
\hline $\begin{array}{l}\text { Normal (BMI 18.5- } \\
24.9 \text { ) }\end{array}$ & 18 & 9 & 27 \\
\hline $\begin{array}{l}\text { Overweight } \\
\text { (BMI 25-29.9) }\end{array}$ & 8 & 2 & 10 \\
\hline $\begin{array}{l}\text { Obese (BMI } 30 \text { or } \\
\text { more) }\end{array}$ & 13 & 19 & 32 \\
\hline Total & 41 & 37 & 78 \\
\hline
\end{tabular}

In our study, none of the cases of IC valve lipomatosis showed evidence of Crohn's disease or ulcerative colitis on the CT scan ( Figure 1).
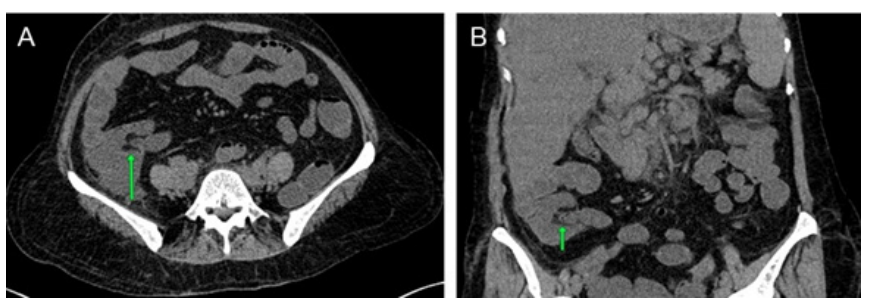

Figure 1: Showing the IC valve lipomatosis in 60 years old obese female patient. Axial (a) \& Coronal (b) images of Unenhanced CT abdomen of 60 years old obese female patient: Arrows show two parallel thick linear areas of fat density at IC junction suggestive of IC valve lipomatosis.

In our study, one patient (Figure 2) showed extensive intestinal lipomatosis involving stomach, duodenum, terminal ileum, IC valve \& colon ( from cecum up to rectum) without any other significant bowel abnormality.
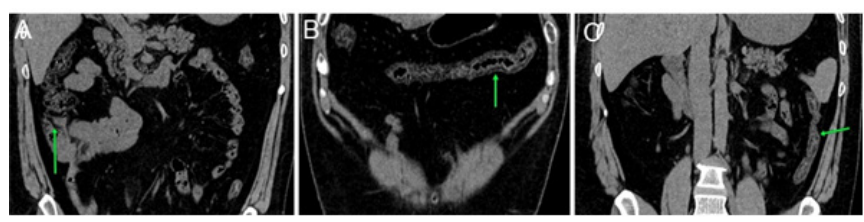

Figure 2: Coronal images of Unenhanced CT abdomen of 35 years old obese male patient having extensive intestinal lipomatosis: Arrow in figure 'a' shows IC valve lipomatosis; Arrow in figure 'b' shows transverse colon lipomatosis; Arrow in figure 'c' shows descending colon lipomatosis.

\section{DISCUSSION}

In intestinal lipomatosis, the fatty tissue deposition is usually limited to the submucosal layer, but it may extend to the serosa and mesenteric fat. ${ }^{3}$ Sometimes intestinal lipomatosis can be associated with diverticulosis. ${ }^{4}$ Intestinal lipomatosis can also be associated with multiple subcutaneous lipomas or diffuse infiltration of fat in the pancreas causing malabsorption due to exocrine pancreatic insufficiency. ${ }^{5}$

The cause of the fat deposition in the IC valve lipomatosis is not known. ${ }^{6}$ Lipomatosis of the IC valve tends to be more common in females. ${ }^{7}$ However in our study, we haven't found female predominance for IC valve lipomatosis. IC valve lipomatosis is uncommon before the age of 40 and is usually seen between 50 and 70 years of age. ${ }^{2}$ However in our study, we had 4 patients in 0-20 years age group \& 22 patients in 21-40 years age group. The mean age in our study was 46.7 years. The mean age in one series was 42.5 
years. ${ }^{7}$ IC valve lipomatosis appears to be associated with generalized obesity. ${ }^{8}$ Results of our study correlate with the previously described association between obesity \& IC valve lipomatosis. In most cases of IC valve lipomatosis, the ileocecal area is otherwise normal, although lipomatosis of the IC valve is a regular feature of Crohn's disease of the terminal ileum. ${ }^{2}$ In our study, no case of IC valve lipomatosis was having CT findings of Crohn's disease or ulcerative colitis.

The majority of cases of IC valve lipomatosis are asymptomatic. When they reach bigger sizes, the symptoms usually start. ${ }^{9}$ The most common manifestations are nonspecific abdominal pain, constipation, diarrhoea and bleeding. ${ }^{9}$ Obstruction, intussusception and massive haemorrhage are rare complications. ${ }^{9}$ It is found that $50 \%$ of patients with lipomatosis have clinical manifestations ${ }^{10}$, whereas $82 \%$ of Lasser and Rigler's ${ }^{11}$ series had abdominal complaints. Lasser and Rigler proposed that a cycle is established in which the enlarged valve tends to cause intussusception and each intussusception causes further enlargement of the valve. Another possibility is that the enlarged valve produces Partial obstruction at the ileocecal junction. ${ }^{2}$ Whether or not the patient's symptoms are related to the enlarged IC valve is difficult to determine. ${ }^{2}$ However, Lasser and Rigler suggested that a definite syndrome exists consisting of bloating, right-sided abdominal pain and tenderness over the ileocecal valve. The term ileocecal valve syndrome was coined by Lasser and Rigler to describe a clinical picture which is presumably based on intermittent intussusception and chronic partial obstruction. Castleman suggests that the symptoms may be due to chronic intussusception, the enlarged valve producing intermittent colocolic intussusception. ${ }^{12}$ There has been a case report of Crohn's ileocolitis associated with lipomatosis of the ileocaecal valve. ${ }^{13}$

In addition to IC valve lipomatosis, several other pathologies can affect ileocecal area such as benign and malignant tumours \& infective/inflammatory pathologies (Crohn's disease, tuberculosis, appendicitis, colitis, diverticulitis). Accurate diagnosis is important for appropriate treatment. On barium enema, it is sometimes difficult to differentiate IC valve lipomatosis from other pathologies of this region. IC valve lipomatosis may be missed on ultrasound unless a high level of suspicion is present. CT scan is the best imaging modality for evaluation of the ileocecal area. On CT scan, IC valve lipomatosis is seen as well-defined homogeneous intramural fat density with an attenuation between -80 and -120 HU. ${ }^{1,14}$ It can be differentiated from a true lipoma, which appears as an asymmetric mass, whereas lipomatosis manifests as symmetric enlargement. ${ }^{14,15}$

IC valve lipomatosis usually requires no treatment as it is asymptomatic in most of the cases. ${ }^{16}$ When it reaches big sizes and produces obstruction or when it is difficult to rule out malignancy, surgical procedures may be required.

\section{CONCLUSION}

It is not uncommon to encounter the IC valve lipomatosis in day-to-day routine radiology practice. As opposed to popular belief, our study suggests that IC valve lipomatosis is not uncommon before 40 years of age. Contrary to popular belief, we haven't found female predominance for IC valve lipomatosis in our study. Results of our study support the association of obesity with IC valve lipomatosis. We haven't found an association of idiopathic inflammatory bowel disease with IC valve lipomatosis in our study.

\section{ACKNOWLEDGEMENT}

The authors acknowledge the immense help received from the scholars whose articles are cited and included in references of this manuscript. The authors are also grateful to the authors/editors/publishers of all those articles, journals, and books from where the literature for this article has been reviewed and discussed.

\section{Conflicts of Interest: None}

\section{Sources of Funding: None}

\section{REFERENCES}

1. Komagata T, Takebayashi S, Hirasawa K, Fukawa T, Arai M. Extensive lipomatosis of the small bowel and mesentery: CT and MRI findings. Radiat Med 2007;25(9):480-3.

2. Berk RN, Davis GB, Cholassey EB. Lipomatosis of the ileocecal valve. Am J Roentgenol 1973;119: 323-328.

3. Parlak S, Okay AE, Altin L, Toprak U, Kuscuoglu G. Lipomatosis of terminal ileum and ileocecal valve: multidetector computed tomography findings. Iranian J Radiol 2014; 11(3):e4336.

4. Ranchod M, French TJ, Novis BH, Bank S, Marks IN. Diffuse nodular lipomatosis and diverticulosis of the small intestine. Gastroenterology 1972;63:667-710.

5. Pariente EA, Cerf M, Corcos D, Debray C. Primary exocrine pancreatic insufficiency in an adult. Gastroenterol Clin Biol 1980;4:275-9.

6. Shenoy R, Rodrigues G, Gopashetty M, Kannaiyan L, Rao S. Segmental jejunal lipomatosis--a rare cause of intestinal obstruction. Yonsei Med J 2003;44(2):359-61.

7. Boquist L, Bergdahl L, Anderson A. Lipomatosis of the ileocaecal valve. Cancer 1972; 29: 136-140.

8. Bhupalan AJ, Forbes A, Lloyd-Davies E, Wignall B. Lipomatosis of the ileocaecal valve simulating Crohn's disease. Postgraduate Med J 1992; 68(800), 455-456.

9. Vasiliadis K, Katsamakas M, Nikolaidou A, Christoforidis E, Tsalis K, Tsalikidis A. Submucosal lipoma of the ascending colon as a source of massive lower gastro-intestinal bleeding: a case report. Acta Chir Belg 2008;108(3):356-9.

10. Kelby GM. Submucous lipomas of ileocecal valve. Lancet 1948, 68, 301-304.

11. Lasser EC, Rigler LG. Ileocecal valve syndrome. Gastroenterology $1955 ; 28,1-16$.

12. Case Records, Massachusetts General Hospital. New Eng Med 1943; 229: 950-953. 
13. Thompson WM. Imaging and findings of lipomas of the gastrointestinal tract. AJR Am J Roentgenol 2005;184(4):1163-71.

14. Hoeffel C, Crema MD, Belkacem A, Azizi L, Lewin M, Arrive L, et al. Multi-detector row CT: spectrum of diseases involving the ileocecal area. Radiographics 2006;26(5):1373-90.
15. Ormson MJ, Stephens DH, Carlson HC. CT recognition of intestinal lipomatosis. AJR Am J Roentgenol 1985;144(2):3134. 